\section{Growth-regulator-induced Alleviation of Chilling Injury in Green and Red Bell Pepper Fruit during Storage}

\author{
Susan Lurie and Reuven Ronen \\ Department of Postharvest Science, The Volcani Center, Agricultural Research \\ Organization, Bet Dagan 50250, Israel
}

\author{
Beny Aloni \\ Department of Field Crops, The Volcani Center, Agricultural Research \\ Organization, Bet Dagan 50250, Israel
}

Additional index words. Capsicum annuum, mefluidide, paclobutrazol, uniconazole

\begin{abstract}
Bell pepper (Capsicum annuum L.) plants were sprayed at full bloom with paclobutrazol (50 and $\left.100 \mathrm{mg}^{-l i t e r}{ }^{-1}\right)$, uniconazole (20 and $50 \mathrm{mg}^{\circ}$ liter $\left.{ }^{-1}\right)$, or mefluidide (20 and $50 \mathrm{mg} \cdot \mathrm{liter}^{-1}$ ). Mature-green and red fruit were harvested 4 and 8 weeks after spraying, respectively. Paclobutrazol and uniconazole, but not mefluidide, affected plant growth and fruit morphology. All three growth regulators alleviated chilling injury that developed on green and red peppers after 28 days at $2 \mathrm{C}$. Potassium leakage was lower from tissue disks, and weight loss less, from treated fruit than from control fruit. Ethylene and $\mathrm{CO}_{2}$ production at $20 \mathrm{C}$ were similar in control and paclobutrazol-treated fruit after 28 days at 2C. These results are consistent with previous findings that showed these growth regulators are able to increase tolerance to low temperatures in whole plants. Chemical names used: $N$-[2,4-dimethyl-5-trifluoromethyl sulfonyl amino phenyl acetamide] (mefluidide); (2RS, 3RS) 1-(4-chlorophenyl)-4,4 dimethyl-2-(1,2,4-triazol-1-yl)-pentan-3-ol (paclobutrazol); (E)-1-(4-chlorophenyl)-4,4-dimethyl-2-(1,2,4 triazol-1-yl)-pentan-3-ol (uniconazole).
\end{abstract}

Triazole plant growth regulators, which include paclobutrazol and uniconazole, inhibit gibberellin biosynthesis and also appear to protect plants against various types of stress, including drought, atmospheric sulfur dioxide, and temperature extremes (Davis et al., 1988; Fletcher and Hofstra, 1988). Triazole compounds protect herbaceous plants from chilling injury (CI) within several days of treatment (Asare-Boamah and Fletcher, 1986; Borochov and Shahar, 1989; Wang, 1985). Whitaker and Wang (1987) concluded that paclobutrazol did not confer chilling resistance by causing significant alterations in lipid composition. They noted, however, that chilling-induced degradation of membrane lipids, which is symptomatic of CI, was inhibited by paclobutrazol.

Mefluidide, an acetamide, protects plants from CI (Borochov and Shahar, 1989; Tseng and $\mathrm{Li}, 1984)$. Abscisic acid synthesis was proposed as the site of mefluidide action, because this hormone accumulates in large amounts following treatment of corn (Zea mays L.) plants with mefluidide even under nonstress conditions (Zhang et al., 1986).

Received for publication 28 Dec. 1993. Accepted for publication $13 \mathrm{Dec}$. 1994. This is publication no. 1263-E, 1993 series, from the Agricultural Research Organization 1994. This work was partially funded by Grant no. 1773 from the United States-Israel Binational Agricultural Research and Development Fund (BARD). The cost of publishing this paper was defrayed in part by the payment of page charges. Under postal regulations, this paper therefore must be hereby marked advertisement solely to indicate this fact.
Abscisic acid increases resistance to a range of environmental stresses (Levitt, 1980).

These compounds could possibly protect fruit normally sensitive to low-temperature storage. The present investigation was conducted to determine if these growth regulators, which are effective in reducing $\mathrm{CI}$ at the wholeplant level, would also confer low-temperature tolerance to fruit harvested from treated plants.

\section{Materials and Methods}

Bell pepper plants ('Maor') were grown in a plastic house and treated at full bloom with sprays of paclobutrazol (50 and $100 \mathrm{mg} \cdot \mathrm{liter}^{-1}$ ), uniconazole (20 and $50 \mathrm{mg} \cdot \mathrm{liter}^{-1}$ ), and mefluidide (20 and $50 \mathrm{mg}$.liter ${ }^{-1}$ ) with $0.02 \%$ Triton X-100 (Sigma, St. Louis) as a surfactant. The control plants were sprayed with $0.02 \%$ Triton X-100 in water. Spraying at this stage has been successfully used to cause earlier and more uniform ripening in tomatoes (Lycopersicon esculentum Mill.) and peppers, allowing for a one-time harvest instead of selective picking (B. Aloni, unpublished; Frost and Kretchman, 1987). Each treatment was applied to three 3-m sections of a row with a plant density of six/meter. One month later, part of the fruit from each section was harvested mature-green, and 2 months later a second harvest was made for red peppers. At the second harvest, only fruit from one concentration (50 mg.liter $\left.{ }^{-1}\right)$ of each growth regulator were harvested. Twenty fruit per section from each treatment (including the control) were placed at $2 \mathrm{C}, 95 \%$ relative humidity, for 28 days. At the end of storage, the fruit were examined for CI and rots. CI was evidenced as surface pitting. If a fruit had more than five pits, regardless of size, it was classified as having CI. Rots were due to either Alternaria alternata Fr. or Botrytus cinerea Pers. ex Fr. Fruit having either or both fungi present were classified as decaying irrespective of the extent of the fungal development.

Upon removal from storage, five fruit each from the control and paclobutrazol treatment were placed at $20 \mathrm{C}$ in individual 1.1-liter jars and $\mathrm{CO}_{2}$ and ethylene production measured daily. The jars were closed for $2 \mathrm{~h}$ and a gas sample of the head space extracted by syringe. Ethylene was measured on a FID-GC (Varian, Sunnyvale, Calif.) with a 1-m alumina column, using $\mathrm{N}$ as the carrier gas, and injector, column, and detector temperatures of 80, 50, and $110 \mathrm{C}$, respectively. Carbon dioxide was determined on a TCD-GC (Varian) with a 2-m Poropak Q column, with $\mathrm{He}$ as the carrier gas at ambient temperature.

Weight loss was determined on 40 fruit from control and the paclobutrazol treatment at $50 \mathrm{mg} \cdot \mathrm{liter}^{-1}$. All fruit were weighed at harvest and then, at varying intervals, 10 fruit from each treatment were removed from storage and weighed again. Firmness and elasticity were measured on 10 fruit from each treatment, by placing a $2-\mathrm{kg}$ weight on the fruit for $20 \mathrm{sec}$ and measuring the resulting deformation in millimeters. Twenty seconds after removing the weight, the residual deformation was noted and termed elasticity. Leakage was determined by placing two rinsed 1 -cm-diameter disks from three fruit of each treatment separately in $5 \mathrm{ml}$ of distilled water and incubating for $3 \mathrm{~h}$ at $25 \mathrm{C}$. Potassium ions leaking from the disks into the incubation solution were measured with a flame photometer. The disks were then frozen, thawed, and ground in $5 \mathrm{ml}$ of water. The solution was filtered and analyzed for total K. Leakage was expressed as the percentage of total $\mathrm{K}$.

Table 1. Incidence of chilling injury (CI) and decay in green and red bell pepper fruit from plants treated with growth regulators at bloom. Peppers were examined after storage for 28 days at $2 \mathrm{C}$.

\begin{tabular}{lcccccc}
\hline \hline $\begin{array}{l}\text { Growth } \\
\text { regulator }\end{array}$ & $\begin{array}{c}\text { Concn } \\
\left(\mathrm{mg} \cdot \text { liter }^{-1}\right)\end{array}$ & \multicolumn{2}{c}{ Fruit with CI (\%) } & & \multicolumn{2}{c}{ Fruit with decay (\%) } \\
\cline { 2 - 4 } None & 0 & 85 & Green & & Green & Red \\
Paclobutrazol & 50 & 41 & 63 & & 5 & 41 \\
& 100 & 12 & --- & & 4 & --- \\
Uniconazole & 20 & 11 & --- & 3 & -- \\
& 50 & 37 & 5 & 9 & 15 \\
Mefluidide & 20 & 16 & --- & 0 & 0 \\
& 50 & 27 & 0 & & 0 \\
LSD $_{0.05}$ & & 8.3 & 7.2 & & 4.3 & 8.7 \\
\hline
\end{tabular}




\section{Results and Discussion}

Paclobutrazol and uniconazole affected plant growth and fruit morphology, while mefluidide did not. The fruit from both triazole growth regulator treatments were less elongated than control or mefluidide-treated fruit, and the plants were smaller and more compact. However, there was no effect on number of fruit per plant (data not shown).

All the growth regulators decreased the incidence CI, manifested as surface pitting, appearing on green or red peppers after 28 days at $2 \mathrm{C}$ (Table 1). The growth regulators also decreased the amount of rots developing after storage, except for paclobutrazol on red peppers. The red peppers were more susceptible to rots than the green, perhaps because they were more mature. Mefluidide was particularly effective in preventing rots in both green and red peppers. The major causal organism was identified as Alternaria alternata, with a minor contribution by Botrytis cinerea.

The firmness of red peppers, measured as resistance to deformation, was not significantly affected by the growth regulators, either at harvest or during storage (Table 2). However, elasticity was greater in control peppers than in those treated with paclobutrazol or mefluidide at harvest, but after storage only the difference between the control and those from the paclobutrazol-treated plants was significant. However, when paclobutrazol-treated and control green peppers were measured weekly, the firmness decreased (deformation increased) and elasticity increased more in control than in treated fruit (Table 3). Weight loss of the control peppers during this period was greater than that of those treated with paclobutrazol. The slopes of the changes in firmness, elasticity, and weight loss between control and paclobutrazol-treated peppers were significant at $P \leq 0.05$. Weight loss has been used as an indicator of CI in citrus (Cohen et al., 1994) and appears to be applicable in the case of peppers as well.

Another measure of tissue damage caused by CI is membrane permeability (Levitt, 1980). Leakage from treated peppers at harvest averaged $19.5 \%$. After 28 days of storage, leakage from control fruit had increased by nearly $50 \%$. Leakage from control fruit was higher than from treated fruit, with the exception of red fruit from paclobutrazol-treated plants (Table 4). The latter treatment also did little to alleviate $\mathrm{CI}$ in the red fruit.

In some tissues, the appearance of CI is accompanied by a transient burst of ethylene production (Wang and Adams, 1982). In the case of green peppers, this was not apparent, and monitoring control and paclobutrazoltreated fruit after removal from storage gave

Table 2. Firmness and elasticity of red bell pepper fruit at harvest and after storage. Plants had been treated with growth regulators $\left(50 \mathrm{mg} \cdot \mathrm{liter}^{-1}\right)$ at full bloom. The fruit were stored for 28 days at $2 \mathrm{C}, 95 \%$ relative humidity, and measured at removal from storage.

\begin{tabular}{lccccc}
\hline \hline \multirow{2}{*}{$\begin{array}{l}\text { Growth } \\
\text { regulator }\end{array}$} & \multicolumn{2}{c}{ Firmness $^{\mathrm{z}}(\mathrm{mm})$} & & \multicolumn{2}{c}{ Elasticity $^{\mathrm{y}}(\mathrm{mm})$} \\
\cline { 2 - 3 } \cline { 5 - 6 } & Harvest & Storage & & Harvest & Storage \\
\hline None & 9.4 & 11.6 & 3.4 & 3.9 \\
Paclobutrazol & 7.5 & 10.5 & 2.4 & 4.2 \\
Uniconazole & 9.3 & 10.3 & 3.3 & 4.3 \\
Mefluidide & 8.5 & 11.4 & 2.4 & 1.09 \\
LSD $_{0.05}$ & 1.92 & 2.22 & 1.00 &
\end{tabular}

${ }^{2}$ Lower values indicate greater resistance to deformation, i.e., firmer fruit

y Lower values indicate closer return to original, undeformed height, i.e., more elastic fruit.

Table 3. Firmness, elasticity, and weight loss of green peppers harvested from nontreated and paclobutrazo (Paclo.)-treated $\left(50 \mathrm{mg} \cdot\right.$ liter $\left.^{-1}\right)$ plants following storage at $2 \mathrm{C}$ for various intervals.

\begin{tabular}{|c|c|c|c|c|c|c|}
\hline \multirow{2}{*}{$\begin{array}{l}\text { Storage } \\
\text { period } \\
\text { (days) }\end{array}$} & \multicolumn{2}{|c|}{ Firmness (mm) } & \multicolumn{2}{|c|}{ Elasticity (mm) } & \multicolumn{2}{|c|}{ Wt loss $(\%)$} \\
\hline & Control & Paclo. & Control & Paclo. & Control & Paclo. \\
\hline 0 & 9.4 & 9.7 & 3.0 & 2.4 & $\begin{array}{ll}-- \\
--\end{array}$ & --- \\
\hline 7 & 9.3 & 10.1 & 3.0 & 2.6 & 1.84 & 1.81 \\
\hline 20 & 10.2 & 9.0 & 4.5 & 2.9 & 4.63 & 3.43 \\
\hline 28 & 12.1 & 9.1 & 5.5 & 3.7 & 5.74 & 3.36 \\
\hline Slope & 0.1 & -0.05 & 0.08 & 0.04 & 0.20 & 0.12 \\
\hline
\end{tabular}

very similar patterns of ethylene and $\mathrm{CO}_{2}$ evolution (data not shown).

In summary, paclobutrazol, uniconizole, and mefluidide all increased low-temperature tolerance of green and red bell pepper fruit. The development of CI on the nontreated fruit was accompanied by increased weight loss and $\mathrm{K}$ leakage, whereas these features were reduced by the growth regulators. Further work is needed to determine the means whereby these compounds, which are given to the plant at bloom, have a sufficient residual effect to protect the fruit from low temperature after harvest.

\section{Literature Cited}

Asare-Boamah, N.K. and R.A. Fletcher. 1986. Protection of bean seedlings against heat and chilling injury by triadimefon. Physiol. Plant. 67:353358.

Borochov, A. and T. Shahar. 1989. Effects of mefluidide and paclobutrazol on growth, flowering and chilling response of gloxinia. Scientia Hort. 39:331-339.

Cohen, E., B. Shapiro, Y. Shalom, and J.D. Klein. 1994. Water loss: A nondestructive indicator of enhanced cell membrane permeability of chilling-injured Citrus fruit. J. Amer. Soc. Hort. Sci. 119:983-986.

Davis, T.D., G.L. Steffens, and N. Sankhlor. 1988. Triazole plant growth regulators. Hort. Rev. 10:63-105.

Fletcher, R.A. and G. Hofstra. 1988. Triazoles as potential plant protectants, p. 321-331. In: C.D. Berg and M. Plempel (eds.). Sterol biosynthesis inhibitors: Pharmaceutical and agrochemical aspects. Ellis Horwood, Cambridge, U.K.

Frost, D.J. and D.W. Kretchman. 1987. Use of
Table 4. Potassium leakage of green and red peppers from plants sprayed with $50 \mathrm{ppm}$ of various growth regulators at full bloom. The fruit were stored for 28 days at $2 \mathrm{C}, 95 \%$ relative humidity. Leakage at harvest averaged $19.5 \%$ with no differences among fruit from the various treatments.

\begin{tabular}{|c|c|c|}
\hline \multirow{2}{*}{$\begin{array}{l}\text { Growth } \\
\text { regulator }\end{array}$} & \multicolumn{2}{|c|}{$\begin{array}{l}\mathrm{K}^{+} \text {leakage }(\% \text { of total }) \\
\text { from fruit } \\
\end{array}$} \\
\hline & Green & Red \\
\hline None & 30 & 27 \\
\hline Paclobutrazol & 24 & 26 \\
\hline Uniconazole & 23 & 21 \\
\hline Mefluidide & 23 & 24 \\
\hline $\mathrm{LSD}_{0.05}$ & 0.7 & 0.7 \\
\hline
\end{tabular}

growth regulators to improve ripening uniformity and yield of processing tomatoes. HortScience 22:422-423.

Levitt, J. 1980. Responses of Plants to Environmental Stresses. 2nd ed. Academic, New York.

Tseng, M.J. and P.H. Li. 1984. Mefluidide protection of severely chilled crop plants. Plant Physiol. 75:249-250.

Wang, C.Y. 1985. Modification of chilling susceptibility in seedlings of cucumber and zucchini squash by the bioregulator paclobutrazol. Scientia Hort. 26:293-298.

Wang, C.Y. and D.O. Adams. 1982. Chilling induced ethylene production in cucumbers (Cucumis sativus L.). Plant Physiol. 69:424-427.

Whitaker, B.D. and C.Y. Wang. 1987. Effect of paclobutrazol and chilling on leaf membrane lipids in cucumber seedlings. Physiol. Plant. 70:404-411.

Zhang, C.L., P.H. Li, and M.L. Brenner. 1986. Relationship between mefluidide treatment and abscisic acid metabolism in chilled corn leaves. Plant Physiol. 81:699-701. 